\title{
EDITORIAL
}

\section{CONTEMPORANEIDADE DE ADORNO NA EDUCAÇÃO: 100 ANOS DO SEU NASCIMENTO}

$\mathscr{P}$ ode-se afirmar sem temor de erro que a crítica é uma das marcas do pensamento moderno e contemporâneo. Trata-se da busca, às vezes confiante, outras desesperada, de encontrar caminhos seguros que garantam ao homem a condição de senhor de si e da história. O fim da Idade Média coincide com o esgotamento das antigas formas de esclarecimento, do mito, da metafísica, da teologia. Cresce a confiança do homem na sua própria capacidade de resolver seus problemas, sem recursos externos. O saber, o conhecimento, o uso correto da razão são os novos meios que, assim a esperança e a promessa, permitiriam ao homem superar os seus medos e satisfazer suas necessidades e desejos. No centro dessa nova perspectiva histórica encontra-se o conhecimento, o domínio e uso da natureza. Fica para trás a idéia de conhecimento que se plenifica na verdade e instalam-se, como novo sentido do conhecer e do agir, a operação e o procedimento eficazes.

Esta nova postura histórica, revolucionária segundo Kant, deveria conduzir o homem para fora de sua menoridade, que consiste na incapacidade de fazer uso do seu entendimento, deveria curá-lo de sua comodidade e covardia, libertá-lo de orientações estranhas. Nasce o sonho de uma nova era esclarecida, livre do jugo das necessidades e feliz, tanto para os indivíduos quanto para a sociedade. Este é o caminho, a narrativa, o futuro que o uso da razão haveria de garantir. Emergia uma nova idéia de salvação e de felicidade não mais projetada para além dos limites da vida terrena: felicidade seria possível aqui mesmo, no tempo, para todos. O caminho? O uso da razão, o conhecimento, a exploração e o uso da natureza. Se antes era a fé, agora seria a razão que garantiria a salvação. 
À pergunta se sua época era esclarecida, Kant respondeu com um enfático não, acrescentando que era, sim, uma época de esclarecimento. Em outros termos dizia que faltava muito para que os homens tivessem condições de fazer uso pleno de sua razão. Esclarecimento, então, deveria ser visto como processo, como busca, aprendizagem. Por isso, a marcha da humanidade no caminho do aperfeiçoamento através da ampliação do saber e do conhecimento está intimamente ligada à educação. O homem torna-se mais racional pela educação e, dessa forma, garante o progresso para o indivíduo e para a sociedade: é a fé no progresso pelo uso da razão.

Este grande e auspicioso cenário que Hegel soube desenhar com plena consciência filosófica, desde cedo foi alvo de severa crítica. Sem falarmos das preocupaçōes epistemológicas, éticas e estéticas de Kant que aí estavam desde a primeira hora do esclarecimento, vale lembrar Nietzsche, Heidegger, Foucault e a Teoria Crítica de Horkheimer e Adorno. Estes últimos protagonizaram, entre os anos 30 e 60 do século XX, um movimento crítico muito rigoroso enfocando evolução da razão moderna. Seu pensamento teve importante repercussão nos mais diferentes campos do saber, desde a sociologia, a filosofia, a ética, a epistemologia, a política, até a crítica da arte e a educação. Do ponto de vista educacional, sua importância maior talvez resida no fato de terem realizado o esclarecimento do esclarecimento, ou seja, apontado as aporias pelas quais enveredou o projeto moderno. A razão que prometera livrar o homem do mito recairia, ela mesma, na órbita do mito, na medida em que, colocando-se por inteiro a serviço da exploração objetalizante da natureza e do homem, transformar-se-ia num novo encantamento, produzindo resultados de tragédia e horror, de dor e sofrimento, sem similares na história. O esclarecimento, assim dizem Adorno e Horkheimer, é a radicalização da angústia mítica.

Esta crítica atinge os fundamentos do projeto educacional moderno na medida em que este não só aceita como tarefa a realização do esclarecimento pelo aprimoramento da razão, mas o acompanha também no fomento dos desvios da razão instrumental. Este modelo de razão tornou-se e continua sendo o centro da práxis educativa. Ora, se ele é perigoso a ponto de produzir os resultados trágicos que todos conhecemos e a educação continua empenhada em seu desenvolvimento, nos vemos em meio a uma contradição de 
incomensuráveis conseqüências. Podemos concordar ou não com as teses de Horkheimer e Adorno, mas, os educadores, não deveríamos ignorá-las nos tempos de perplexidade em que vivemos.

São estas as razões que levam Educação \& Sociedade a oferecer um dossiê aos seus leitores com alguns resultados das reflexões e pesquisas que vêm sendo desenvolvidas por um grupo de intelectuais que se dedicam ao estudo sistemático deste conjunto de autores e temas. O objetivo é de enriquecer o debate que, desde perspectivas teóricas distintas, vem sendo realizado sobre a realidade humana e social e, por conseguinte, também educacional, que é tida, igualmente por pessimistas e otimistas, como profundamente problemática e contraditória.

Comitê Editorial 